\title{
IMPLEMENTASI SUPERVISI PENDIDIKAN DALAM MENINGKATKAN MUTU PEMBELAJARAN (STUdI KaSUS DI MADRASAH ALIYAH NEGERI 3 KEDIRI)
}

\author{
Miftahul Ngulya, Asep Kurniawan \\ Prodi Manajemen Pendidikan Islam Fakultas Agama Islam \\ Universitas Hasyim Asy'ari Tebuireng Jombang \\ Miftahululya27@gmail.com
}

\begin{abstract}
Educational supervision is all forms of assistance provided by school leaders to improve the ability of teachers and other personnel to achieve the goals of education. This study aims to determine the implementation of educational supervision in improving the quality of learning in MAN 3 Kediri. The method used for data collection is done by observation, interviews, and documentation, while the data analysis technique uses a descriptive qualitative research approach, which is interpreted through descriptive explanations as conclusions about supervision in improving the quality of learning. From the results of the study, it can be concluded that: Implementation of educational supervision in MAN 3 Kediri is carried out by arranging supervision programs, involving all waka, conducting upgrading through class visits, class observations, MGMP by visiting each other, training/workshops, evaluations and actions continued. In improving the quality of learning, it is carried out in collaboration with teachers in strengthening the curriculum and developing learning tools, providing learning resources, tools and various teaching and learning facilities. Implementation of educational supervision in improving the quality of learning, through guidance and curriculum development, improving teaching and learning processes, and efforts to enhance the quality of teachers through coaching and up grading. Obstacles to the implementation of educational supervision in improving the quality of learning, namely: some teachers have not been able to deliver the material well, impromptu activities, facilities and infrastructure are damaged, coaching is often done on holidays. While the supporting factors are as follows: guidance on the content and concepts of curriculum thinking, internet facilities, madrasa books, socialization, certified teachers, adequate facilities and infrastructure in carrying out teaching and learning processes.
\end{abstract}

Keywords: educational; supervision; quality of learning 


\begin{abstract}
ABSTRAK
Supervisi pendidikan merupakan segala bentuk bantuan yang diberikan oleh pemimpin sekolah kepada untuk meningkatkan kemampuan guru-guru dan personil lainnya guna mencapai tujuan dari pendidikan. Penelitian ini bertujuan untuk mengetahui implementasi supervisi pendidikan dalam meningkatkan mutu pembelajaran di MAN 3 Kediri. Metode yang digunakan untuk pengumpulan data dilakukan dengan observasi, wawancara, dan dokumentasi, sementara teknik analisis datanya menggunakan pendekatan penelitian kualitatif deskriptif. Hasil dari penelitian yaitu, Implementasi supervisi pendidikan di MAN 3 Kediri dilaksanakan dengan menyusun program supervisi, dengan melibatkan semua waka, mengadakan penataran-penataran melalui kunjungan kelas, observasi kelas, MGMP dengan saling mengunjungi, pelatihan/workshop, evaluasi dan tindak lanjut. Dalam meningkatkan mutu pembelajaran, dilakukan melalui kerja sama dengan guru-guru dalam pemantapan kurikulum dan penyusunan perangkat pembelajaran, menyediakan sumber-sumber belajar, alat serta berbagai fasilitas belajar mengajar. Implementasi supervisi pendidikan dalam meningkatkan mutu pembelajaran, melalui pembinaan dan pengembangan kurikulum, meningkatkan proses belajar mengajar, dan upaya mempertinggi kualitas guru melalui pembinaan dan up grading. Hambatan Implementasi supervisi pendidikan dalam meningkatkan mutu pembelajaran yaitu: beberapa guru belum mampu menyampaikan materi dengan baik, kegiatan dadakan, sarana dan prasarana rusak, pembinaan sering dilakukan di hari libur. Sedangkan faktor pendukungnya sebagai berikut: pembinaan terhadap isi dan konsep berpikir kurikulum, fasilitas internet, bukubuku madrasah, sosialisasi, guru sudah tersertifikasi, mencukupi sarana dan prasarana dalam melaksanakan proses belajar mengajar.
\end{abstract}

Kata kunci : supervisi: pendidikan; mutu pembelajaran.

\title{
I. Pendahuluan
}

Dalam dunia pendidikan dalam meningkatkan mutu Sumber Daya Manusia guna memperbaiki mutu pendidikan, pemerintah sudah berusaha memperbaiki kurikulum, peningkatan kualitas guru, memberikan sarana dan prasarana, menyejahterakan guru, perbaikan organisasi, perbaikan manajemen, pengawasan serta perundang-undangan. Tujuannya agar dilihat kinerja yang lebih baik dan mampu menciptakan pendidikan bermutu.

Dapat dilihat pendidikan nasional yang belum bisa dikatakan kurang bermutu, susah jika memutuskan salah satu masalah, karna tidak akan berujung. Hingga akhirnya pencarian akan sampai pada jantung yaitu proses belajar mengajar yang dikelola guru harus diperhatikan, sebab di sinilah pusat kegiatan pembelajaran.

Dalam sebuah kajian yang dikaji oleh Depdiknas, Bappenas, dan bank dunia mengatakan bahwa guru merupakan kunci utama dalam meningkatkan mutu, karena mereka merupakan kunci keberhasilan dalam meningkatkan mutu pendidikan. Masalah 
mutu pembelajaran merupakan masalah yang sangat esensial yaitu kualitas guru dalam melangsungkan tugas mengajar. Oleh karna itu guru harus memperoleh pengawasan dalam bentuk pembinaan profesional yang dilakukan secara kontinu. (Sulistyorini, 2009)

Definisi supervisi pendidikan mempunyai pengertian yang sangat beragam. Supervisi yaitu segala bentuk bantuan dari pemimpin sekolah, yang diarahkan kepada perkembangan guru-guru dan staf lainnya untuk mencapai tujuan pendidikan. Bantuan yang diberikan bisa berupa dorongan, bimbingan, kesempatan untuk tumbuh bersama sesuai keahlian dan kecakapan guru, seperti bimbingan dan usaha serta pelaksanaan dalam pendidikan dan pengajaran, menentukan media pembelajaran, dan metode mengajar yang sesuai, penilaian yang tepat terhadap semua proses pengajaran, dan lainlain. Dengan kata lain: Supervisi adalah seluruh aktivitas pembinaan yang telah direncanakan sebelumnya sebagai bantuan kepada guru-guru dan staf lainnya dalam melaksanakan tugasnya.

Fungsi supervisi dalam pendidikan tidak hanya sekedar melihat apakah seluruh kegiatan telah berjalan sesuai dengan program yang telah ditetapkan, namun lebih dari itu. Kegiatan supervisi menyangkut situasi-situasi, atau syarat-syarat yang dibutuhkan untuk mewujudkan situasi pembelajaran yang bermutu. (Purwanto, 2012)

Dalam kegiatan supervisi pendidikan, penyusunan program harus ada tiga komponen yaitu: personil, operasional, material. Ketiga komponen tersebut merupakan situasi belajar mengajar, dan pembelajaran sebagai sebuah proses. Operasional mencakup semua aktivitas individu atau kelompok yang berada dalam satu lingkup dengan menggunakan seluruh sumber yang ada baik human Resource maupun non human resource untuk mewujudkan tujuan pendidikan dan pengajaran yang diharapkan. Sedangkan material yaitu seluruh benda atau barang baik yang bersifat hard ware maupun soft ware, yang didayagunakan untuk kelancaran proses pembelajaran. Untuk memudahkan pemahaman terhadap komponen-komponen situasi belajar mengajar dalam supervisi pendidikan. Adapun aspek personel yaitu subyek atau orangorang yang menjadi bagian dalam supervisi pendidikan. (Burhanuddin, 2007)

Kepala Madrasah sebagai supervisor diharapkan mampu membaca kebutuhan guru atau staf lainnya, sehingga dapat membantu dalam menjalankan tugasnya. Meningkatkan mutu pembelajaran merupakan landasan profesionalnya supervisi pendidikan. Oleh karna itu, dibutuhkan perubahan dan pengembangan visi dan misi yang berlandaskan pada mutu, prestasi siswa, dan pikiran baru pendidikan.

Tujuan dari penelitian ini adalah mengetahui implementasi supervisi pendidikan dan mengetahui faktor pendukung dan penghambat implementasi supervisi pendidikan dalam meningkatkan mutu pembelajaran di MAN 3 Kediri. 


\section{Metodologi Penelitian}

Penelitian ini adalah penelitian kualitatif. Penulis melakukan pengumpulan data dengan cara observasi lapangan di sekolah MAN 3 Kediri. Selain itu, penulis juga melakukan wawancara kepada sejumlah pihak penting di sekolah tersebut, seperti kepala sekolah, wakil kepala sekolah, guru, staf tata usaha dan lain-lain. Penulis mencoba mengikuti segala kegiatan yang diselenggarakan sekolah dan mendokumentasikannya. Teknik analisis data yang penulis gunakan dengan pendekatan penelitian kualitatif deskriptif.

\section{Pembahasan}

\section{A. Implementasi Supervisi pendidikan}

Supervisi pendidikan dilaksanakan untuk memberikan kemudahan terhadap jalannya program pendidikan yang sesuai dengan standar pendidikan nasional yang telah ditentukan dengan memperhatikan tujuan pendidikan. Meskipun penerapannya di lapangan bisa saja terdapat sumber daya manusia yang belum menggambarkan sikap profesionalitas. Supervisi pendidikan merupakan tugas kepala madrasah sebagai pimpinan yang menjadi ketua dari satuan sebuah pendidikan. (Fauziah, 2017)

Implementasi supervisi pendidikan MAN 3 Kediri di lakukan di awal semester dengan menyusun program supervisi pendidikan sesuai dengan Badan Standar Nasional Pendidikan masuk dalam Surat Keputusan pembelajaran, memuat jadwal supervisi pelaksanaan supervisi dan instrumen-instrumen pelaksanaan supervisi.

Pelaksana supervisi pendidikan MAN 3 Kediri yaitu kepala madrasah sebagai supervisor dibantu tim supervisi. Hal ini dikarenakan jumlah kelas yang harus disupervisi dirasa terlalu banyak jika pelaksana supervisi hanya dilakukan oleh kepala madrasah. Program supervisi pendidikan MAN 3 Kediri dilaksanakan sesuai jadwal yang sudah disepakati dalam rapat tim supervisi. Sebagai bantuan dan pelayanan kepada guru dalam meningkatkan situasi belajar mengajar. Maka selain jadwal supervisi dan pelaksana supervisi, tim supervisi juga menyusun instrumen-instrumen supervisi pendidikan.

Pendekatan supervisi dilakukan dengan teknik supervisi akademik yaitu melalui rapat antara kepala madrasah dengan guru. Kegiatan ini dilakukan guna memecahkan permasalahan yang terjadi dalam lingkup pendidikan, untuk setelahnya dilakukan upaya perbaikan. (Desi \& Roemintoyo, 2018)

Melihat pendekatan atau teknik supervisi tidak bisa dipisahkan dari tipe guru, maka implementasi supervisi pendidikan di MAN 3 Kediri dilakukan dengan pendekatan supervisi kolaboratif yaitu kepala madrasah dan guru berbagi tanggung jawab bersama 
guru-guru terkait tugas mengajar dengan mendengarkan dan memahami masalah apa yang dihadapi guru ketika mengajar, kemudian kepala madrasah mengemukakan pandangannya perihal masalah yang dihadapi guru. Berdasarkan beberapa prinsip, di antaranya Prinsip IImiah (scientific), yaitu berdasarkan data obyektif yang diperoleh dalam dari kunjungan kelas dan observasi kelas ketika pelaksanaan proses belajar mengajar. Prinsip demokratis, berupa bantuan yang diberikan kepala madrasah berdasarkan kedekatan dengan guru. dan Prinsip kerja sama, kepala madrasah mengembangkan usaha bersama serta memberi dorongan guru, sehingga merasa tumbuh bersama.

Dalam pelaksanaannya supervisi pendidikan di MAN 3 Kediri dilakukan Melalui beberapa teknik, yaitu kunjungan kelas serta observasi kelas dalam bentuk supervisi oleh kepala madrasah dibantu tim supervisi. Sebagai tindak lanjut dari pelaksanaan supervisi kunjungan kelas dan observasi kelas, maka perlu dilakukan pengecekan terkait perangkat pembelajaran melalui percakapan pribadi antara supervisor dan guru. Dalam percakapan tersebut, kepala madrasah dan guru saling bertukar pikiran dan sepakat untuk menetapkan rencana pembelajaran, proses pembelajaran dan kriteria hasil pembelajaran yang akan dicapai.

\section{B. Meningkatkan Mutu Pembelajaran}

Mutu pembelajaran adalah situasi dan gambaran keseluruhan baik berupa jasa atau layanan pendidikan baik internal maupun eksternal, serta memiliki kemampuan dalam memenuhi kebutuhan yang direncanakan, mencakup input, proses, dan output pendidikan (Sagala, 2010)

Dalam meningkatkan mutu pembelajaran MAN 3 Kediri berpijak pada kemampuan guru dalam mengelola proses pembelajaran. Guru harus dapat merancang model pembelajaran, merumuskan berbagai pengalaman belajar dan berbagai kegiatan dalam sebagai ketuntasan belajar.

Meningkatkan mutu pembelajaran dengan memilih, menetapkan dan mengembangkan metode pembelajaran, maka seorang guru harus mengetahui empat hal yang ada dalam situasi pembelajaran yaitu: (1) tujuan pembelajaran (2) isi pembelajaran (3) sumber belajar sebagai media pengantar materi pembelajaran dan (4) karakter peserta didik yang berhubungan dengan kemampuan peserta didik. (Muhaimin, 2004)

Guru sebagai pelaksana kurikulum diharapkan mampu berinteraksi dengan siswa, melalui interaksi tersebut, guru dapat mengerti kebutuhan siswa dan memahami karakteristik siswa seperti kemampuan dasarnya, motivasinya, latar belakang akademisnya, dan sebagainya. Sehingga guru merasa terbantu dalam menyajikan dan menguraikan tujuan pembelajaran, isi pembelajaran dan sumber pembelajaran. 
Tujuan pembelajaran berpengaruh terhadap pemilihan metode yang hendak digunakan. Metode dalam mengajar berperan sebagai alat untuk menciptakan situasi belajar mengajar yang terjalin antara guru dengan siswa, sehingga metode pembelajaran dapat dikembangkan. Pemilihan metode, MAN 3 Kediri tidak membatasi, guru dapat merancang atau menggunakan lebih dari satu metode pembelajaran agar materi yang disampaikan guru dapat sampai ke siswa.

Metode pembelajaran yang baik memerlukan sumber dan media yang berbedabeda, tergantung karakteristik mata pelajaran yang dikaji. Dalam hal ini MAN 3 Kediri Mencukupi media dan sumber pembelajaran, guru bisa memilih sumber dan media belajar sesuai dengan materi pembelajaran yang dikaji sehingga memudahkan pemahaman siswa.

Lebih lanjut MAN 3 Kediri memberi fasilitas pembelajaran sebagai penyesuaian diri siswa untuk berinteraksi dengan lingkungannya. Melalui pembelajaran full day school dan boarding school, serta kegiatan adiwiyata, siswa dapat berinteraksi dengan lingkungannya dan memberi pengalaman baru untuk cinta lingkungan. Hal ini mengacu guru berkreasi menerapkan strategi pembelajaran yang bervariasi dalam proses belajar mengajar dengan setting yang berbeda-beda, dengan begitu siswa tetap antusias dan tidak merasa jenuh dengan materi yang diajarkan hingga mata pelajaran tersebut selesai.

\section{Implementasi Supervisi Pendidikan dalam Meningkatkan Mutu Pembelajaran}

Program supervisi merupakan prosedur pembinaan yang kegiatannya dirancang untuk guru dengan bahasan-bahasan yang memuat penyajian informasi dari suatu jenis pendekatan, tujuannya, membantu guru menerima informasi baru, memberi pemahaman pengajaran, dan memberi pengalaman baru tentang tingkat pengetahuan serta integrasi nilai dan sikap. Supervisi pendidikan meliputi: (1) Obyek kegiatan supervisi yaitu guru dalam pembelajaran peserta didik; (2) subyek kegiatan supervisi yaitu semua personil madrasah (kepala madrasah, guru, dan tenaga pendidikan lainnya) baik secara langsung ataupun tidak langsung membantu guru dalam menyelesaikan masalah pembelajaran; (3) kegiatan supervisi dilakukan secara terencana dengan proses jangka panjang; (4) sasaran kegiatan supervisi yaitu memecahkan permasalahan sebagai upaya perbaikan proses pendidikan ke arah yang lebih baik. (Burhanuddin, 2007:110).

Implementasi Supervisi pendidikan di MAN 3 Kediri dilakukan baik tenaga pendidik dan tenaga pendidikan. Kegiatan ini dimulai sebelum masuk semester melalui rapat bersama guru-guru dan tenaga pendidikan lainnya, untuk pembagian tugas dan pekerjaan guru sekaligus petunjuk dalam mempersiapkan perangkat pembelajaran. Dalam kegiatan tersebut kepala madrasah memberi arahan kepada guru dalam menjalankan kegiatan profesionalnya, dengan membina hubungan kooperatif, yaitu bersama-sama berusaha mempertinggi kemampuannya. 
Perangkat pembelajaran yang harus dipenuhi guru meliputi Program tahunan, Program semester, Silabus, KKM, RPP, kisi-kisi, dan Soft file. Terkait administrasi yang harus dipenuhi guru dalam mempersiapkan perangkat pembelajaran, maka dibuatlah form sebagai bentuk pantauan yang dilakukan tim supervisi untuk mengetahui mana tugas guru yang sudah dan yang belum dilaksanakan.

Implementasi supervisi pendidikan di MAN 3 Kediri dilakukan oleh tim supervisi sesuai jadwal beserta instrumen pelaksanaan supervisi sebagai pedoman dan sebagai alat ukur keberhasilan proses belajar mengajar. Karena aspek utamanya adalah guru, maka layanan ke supervisian lebih ditekankan pada peningkatan dan perbaikan kemampuan guru dalam membina proses pembelajaran yang lebih baik.

Kegiatan supervisi kunjungan kelas dilakukan oleh kepala madrasah dengan mengamati proses belajar mengajar yang dilakukan oleh guru ketika mengajar, guna melihat kekurangan dan kelebihan dari kegiatan pembelajaran. Teknik ini merupakan tugas kepala madrasah dalam melaksanakan supervisi pendidikan (Desi \& Roemintoyo, 2018)

Pelaksanaan supervisi dalam meningkatkan mutu pembelajaran di MAN 3 Kediri dilakukan melalui berbagai teknik, di antaranya kunjungan kelas dan observasi kelas oleh kepala madrasah dibantu tim supervisi. Melalui kunjungan kelas dan observasi kelas dapat mengetahui apakah guru-guru menjalankan proses pembelajaran sesuai dengan RPP yang disusun, serta melihat langsung kemampuan guru mengajar dikelas.

Observasi kelas bertujuan memperoleh data yang obyektif sehingga dapat digunakan untuk dianalisis kesulitan-kesulitan yang dihadapi guru-guru dalam melaksanakan pembelajaran, bagi guru sendiri data yang dianalisis dapat membantu guru untuk mengajar lebih baik, bagi siswa dapat memberikan pengaruh positif terhadap kemajuan belajar mereka.

Kegiatan supervisi pertemuan pribadi dilakukan secara pribadi yaitu pertemuan kepala madrasah dengan guru dalam ruangan tertentu. Teknik ini diharapkan dapat memberi masukan juga memberi bantuan kepada guru terhadap masalah yang dihadapi, dan guru dapat menggunakan media, sumber belajar dan metode pembelajaran dengan baik. Kepala madrasah juga memberi motivasi berupa dorongan kepada guru untuk selalu meningkatkan pengetahuannya. (Desi \& Roemintoyo, 2018)

Guru sebagai pelaksana kurikulum harus senantiasa meningkatkan kemampuannya. Melalui pelatihan dan workshop baik dari petugas pendidikan, undangan Diknas, kementerian agama atau instansi tertentu, guru-guru MAN 3 Kediri dapat memperluas pengetahuannya, bertambah ketrampilan mengajar dan meningkatkan profesionalitas mereka. Sehingga guru-guru semakin profesional dalam mengelola proses pembelajaran. 


\section{Faktor Penghambat Dan Pendukung Implementasi Supervisi Pendidikan Dalam Meningkatkan Mutu Pembelajaran}

Implementasi supervisi pendidikan sering kali terhambat oleh problematik yang tidak ringan. Kepala madrasah sebagai supervisor berkewajiban menangani masalahmasalah tersebut yang bisa menghambat jalannya implementasi supervisi pendidikan dalam meningkatkan mutu pembelajaran.

Problematik supervisi pendidikan telah terangkum dalam testimoni pelaku pendidikan yang beragam. Pemahaman kurikulum harus dibereskan dan pemahaman mengenai keadaan siswa yang senantiasa berubah jalan cerita harus diselesaikan. Salah satu jalan keluar yang dapat diambil sebagai sebuah keharusan yaitu supervisi sebagai pendorong semangat pengajar untuk selalu mengembangkan kemampuan mengajarnya. (Fauziah, 2017)

\section{Faktor Penghambat Implementasi Supervisi Pendidikan dalam Meningkatkan Mutu \\ Pembelajaran}

Sebagai usaha membina dan meningkatkan potensi sumber daya guru dalam tugas mengajar, jika dilihat dari sifat hambatan dikaitkan dalam proses belajar mengajar, hambatan guru dapat dikelompokkan menjadi dua yaitu:

1) Masalah umum yang sering kali dihadapi guru dalam melaksanakan tugasnya.

2) Masalah khusus yang diterima guru (Sahertian, 2008)

Hambatan implementasi supervisi pendidikan di MAN 3 Kediri kembali kepada guru dalam melaksanakan tugasnya sebagai pengelola pembelajaran. Hal ini dikarenakan beberapa guru belum mampu mengembangkan metode atau materi sesuai dengan kurikulum. Proses belajar mengajar juga belum dapat berjalan maksimal, dikarenakan adanya kegiatan-kegiatan yang sifatnya dadakan tanpa bisa diprediksi sebelumnya. Proses belajar mengajar di dalam kelas juga demikian, beberapa LCD dikelas tidak bisa digunakan.

Sebagai madrasah pelaksana fulldayschool, pembelajaran MAN 3 Kediri relatif lebih lama, dalam waktu satu minggu jam mengajar guru lebih dari 30 jam dengan jumlah murid seribu lebih, maka pembinaan sering kali dilakukan di hari libur. Sebenarnya pembinaan bisa dilakukan di hari efektif dengan konsekuensi proses belajar mengajar dan kesehatan guru terganggu.

\section{Faktor Pendukung Implementasi Supervisi Pendidikan dalam Meningkatkan Mutu Pembelajaran}

Melalui supervisi pendidikan dapat diketahui beberapa masalah dalam meningkatkan mutu pembelajaran yang perlu ditindak lanjuti. Terutama masalah yang 
dihadapi guru. Supervisi membantu guru dalam memecahkan masalah yang dihadapi dalam pembelajaran dan berbagai langkah untuk membantu guru meningkatkan kualitas pembelajaran.

Metode atau materi yang disampaikan guru dalam proses pembelajaran harus disesuaikan dengan kurikulum. Maka setiap kurikulum yang akan diterapkan di MAN 3 Kediri harus dilakukan pembinaan terhadap isi dan konsep berpikir kurikulum. Melalui pembinaan kurikulum, guru-guru dapat mengetahui tugas-tugasnya, dapat menyusun perangkat pembelajaran sesuai ketentuan dan dapat mengembangkan metode dan materi dengan baik.

Ketika menyusun perangkat pembelajaran, guru-guru MAN 3 Kediri dapat memanfaatkan fasilitas internet untuk melihat contoh terkait tugas-tugas, juga dapat membaca buku yang sudah disediakan madrasah. Untuk menambah pengetahuan guruguru dalam melaksanakan tugasnya, sering kali diadakan sosialisasi baik kepala madrasah sendiri yang bertindak sebagai narasumber atau dengan mengundang pengawas sebagai narasumber.

Dalam meningkatkan mutu pembelajaran diperlukan guru yang bermutu pula. Dalam hal ini guru-guru MAN 3 Kediri mayoritas sudah sertifikasi atau sudah profesional yang mampu bertindak sebagai pengelola proses pembelajaran dan mempunyai kemampuan dalam merancang program pembelajaran, melaksanakan proses pembelajaran, hasil belajar dan mengembangkan manajemen kelas sesuai dengan bidang ilmunya.

Sebagai media dan sumber belajar, MAN 3 Kediri mencukupi sarana dan prasarana yang dapat dimanfaatkan guru, agar proses belajar mengajar dapat berjalan dengan baik. Maksudnya melalui proses pembelajaran diharapkan siswa dapat memperoleh pengalaman belajar, pengetahuan baru, dan belajar sebagai perubahan tingkah laku.

\section{KesIMPULAN}

Implementasi supervisi pendidikan di MAN 3 Kediri dilakukan di awal semester dengan menyusun program supervisi pendidikan sesuai dengan Badan Standar Nasional Pendidikan, memuat jadwal supervisi pelaksanaan supervisi dan instrumen pelaksanaan supervisi.

Dalam meningkatkan mutu pembelajaran, MAN 3 Kediri berpijak pada kemampuan guru pada saat berlangsungnya proses belajar mengajar. Melalui pembelajaran full day school dan boarding school, serta kegiatan adiwiyata, mengacu guru berkreasi menerapkan strategi pembelajaran yang bervariasi, hal ini ditunjang dengan sarana dan prasarana serta guru mengajar sesuai dengan disiplin ilmunya. 
Implementasi supervisi pendidikan dalam meningkatkan mutu pembelajaran di MAN 3 Kediri dilakukan baik tenaga pendidik dan tenaga pendidikan. Adapun implementasi supervisi di MAN 3 Kediri dilakukan melalui: kunjungan kelas, observasi kelas, kelompok studi antar guru, pelatihan/ penataran, dan workshop.

Beberapa faktor penghambat Implementasi supervisi pendidikan dalam meningkatkan mutu pembelajaran di MAN 3 Kediri yaitu: (1) beberapa guru belum mampu menyampaikan materi dengan baik, (2) kegiatan dadakan, (3) sarana dan prasarana rusak, (4) pembinaan sering dilakukan di hari libur. Sementara faktor yang mendukung implementasi supervisi dalam meningkatkan mutu pembelajaran sebagai berikut: (1) pembinaan terhadap isi dan konsep berpikir kurikulum, (2) fasilitas internet, (3) buku-buku madrasah, (5) sosialisasi, (6) guru sudah tersertifikasi, (7) mencukupi sarana dan prasarana sebagai penunjang pembelajaran.

\section{Daftar Pustaka}

Burhanuddin, dkk. (2007). Supervisi Pendidikan dan Pengajaran. Malang: Fakultas Ilmu Pendidikan Universitas Negeri Malang.

Desi, R., \& Roemintoyo, W. (2018). Implementasi Teknik Supervisi Akademik Kepala Sekolah Terhadap Pendidik di Sekolah Dasar untuk Menghadapi Era Digital”. JMSP.3.

Fauziah. (2017). Supervisi Pendidikan sebagai Upaya Peningkatan Mutu Pendidikan Islam"(Vol. Januari). Tarbiyatuna.2.

Muhaimin. (2004). Paradigma Pendidikan Islam. Cet. 3. Bandung: PT Remaja Rosdakarya.

Purwanto, N. (2012). Administrasi dan Supervisi Pendidikan. Bandung: PT Remaja Rosdakarya.

Sagala, S. (2010). Manajemen Strategik dalam Peningkatkan Mutu Pendidikan. Bandung: Alfabeta.

Sahertian, P. A. (2008). Konsep Dasar Dan Teknik Supervisi Pendidikan. Cet. 2. Jakarta: PT Rineka Cipta.

Sulistyorini. (2009). Manajemen Pendidikan Islam Konsep Strategi dan Aplikasi. Yogyakarta: Teras. 